\title{
Untreated and formaldehyde-treated urea as nitrogen sources for young growing bulls
}

\author{
JOUKO SETÄLÄ, LIISA SYRJÄLÄ-QVIST and PENTTI ASPILA
}

\author{
Department of Animal Husbandry, University of Helsinki, 00710 Helsinki \\ 71, Finland
}

\begin{abstract}
Untreated urea and urea treated with $1.5 \%$ formaldehyde were compared as nitrogen sources for young growing bulls. The experiment was performed with 12 individually fed animals, eight of which were Friesians and four Finnish Ayrshires, and the average age of the animals at the beginning of the experiment was about 3.5 months. After a standardization period of two weeks, the animals were divided into two groups with similar distributions by daily gain, feed utilization, liveweight and age. During the following transition period of one week the feeding of the animals was changed to the experimental diets of the 24-week test period.

The feeding was based on $\mathrm{NaOH}$-treated barley straw and a mixture of barley, oats and molassed beet pulp, and planned for a daily gain of $1000 \mathrm{grams} /$ animal. During the standardization period the animals received $2.9 \%$ untreated urea in the concentrate, and soybean meal was also used to bring the feeding into agreement with the standards chosen. During the test period the animals received untreated or treated urea and their contributed about $35-40 \%$ of their DCP requirements.

There were no significant differences between the groups in daily gain, feed utilization or slaughter results. Nor did the two groups show any significant differences in plasma urea, albumin and total proteins. The plasma concentrations of aspartate aminotransferase, alanine amino transferase and creatinine did not differ significantly between the groups.
\end{abstract}

\section{Introduction}

According to recent information on the nitrogen metabolism of ruminants, it is possible to divide their nitrogen requirements into two groups. Besides feed protein nitrogen that is not degradable in the rumen, rumendegradable nitrogen is important for the performance of beef cattle, especially at the end of the growth period (HUGHES et al. 1980, ROY 1980).

Urea is a suitable source of rumen-degradable nitrogen, but since it is rapidly hydrolysed to ammonia, the utilization of urea nitrogen by beef cattle is dependent on the digestible organic matter content of the diet (GABEL and POPPE 1979). The utilization of urea can also be affected and improved by formaldehyde treatment, as ahown by SETÄLÄ and SYRJÄLÄ-QVIST (1982 a, $\mathrm{b}, \mathrm{c}, \mathrm{d})$ in vitro, and in physiological and milk production studies performed 
with sheep and dairy cows. The aim of this experiment was to compare untreated and formaldehyde-treated urea as nitrogen sources for young growing bulls.

\section{Materials and methods}

The experiment was performed with 12 growing bulls, which came to the experiment in two blocks. One of the animals in the untreated-urea group had to be slaughtered at the beginning of the test period, owing to chronic inflammation of the abomasum. Before the 24-week test period the animals had a standardization period of two weeks, after which they were divided into two groups resembling each other in their distribution by age, liveweight gain, liveweight and feed utilization. During a one week transition period between the standardization and test periods, the feeds of the animals were changed to the experimental diets. At the beginning of the experiment the average age and weight of the animals were 107 days and $106 \mathrm{~kg}$. The animals were weighed on two successive days before the morning feeding at the beginning and end of the different periods. During the test period weighing was performed once every third week before the morning feeding.

\section{Feeds and feeding}

During the standardization period, the animals received baled hay and $\mathrm{NaOH}$-treated barley straw as their roughage and a concentrate mixture of barley ( $42 \%)$, oats ( $42 \%)$, molassed beet pulp (13.4\%) and minerals $(2.6$ $\%)$. The feeding was planned for a growth rate of 1000 grams/day according to the standards of BRÄNNANG and EKMAN-BJÄRESTEN (1965). The animals had received urea before the start of the experiment, and during the standardization period $2.9 \%$ untreated urea was added to their concentrate. Soybean meal was also used according to the above standards, when this was necessary to meet the animals'requirements for DCP.

For the test period, the animals were divided into two groups, one of which received untreated urea and the other urea treated with $1.5 \%$ formaldehyde $(\mathrm{HCHO})$ in their concentrate mixture (Table 1). $\mathrm{NaOH}$-treated barley straw (Table 2) was used as roughage and a small amount of hay was also given at the beginning of the period to bring the feeding into agreement with the standards. The animals were fed individually. The treatment of urea with HCHO was as described by SETÄLÄ and SYRJÄLÄ-QVIST(1982 a).

\section{Sampling and analyses}

The roughage was sampled every third week and the concentrate when the mixture was made, the ingredients being sampled and analyzed separately. Feed refusals were sampled as described by SETÄLÄ and SYRJÄLÄ-QVIST 
Table 1. The ingredients of the concentrate mixture.

\begin{tabular}{|c|c|c|}
\hline & \multicolumn{2}{|c|}{ Groups } \\
\hline & Untreated urea & $1.5 \% \mathrm{HCHO}$-treated urea \\
\hline Barley & 41.3 & 41.3 \\
\hline Oats & 41.3 & 41.3 \\
\hline Molassed beet pulp & 12.5 & 12.5 \\
\hline Mineral mixture ${ }^{1}$ ) & 2.0 & 2.0 \\
\hline Untreated urea & 2.9 & - \\
\hline $1.5 \% \mathrm{HCHO}$-treated urea & - & 2.9 \\
\hline
\end{tabular}

1) $\mathrm{g} / \mathrm{kg}$ : Ca $175, \mathrm{P} 80, \mathrm{Na} 95, \mathrm{Mg} 50, \mathrm{Se} 0.01$

Table 2. Chemical composition and feeding value of the feeds.

\begin{tabular}{|c|c|c|c|c|c|}
\hline & $\begin{array}{c}\text { Concentrate } \\
\text { mixture }\end{array}$ & Hay & $\begin{array}{l}\mathrm{NaOH} \text {-treated } \\
\text { straw }\end{array}$ & $\begin{array}{c}\text { Untreated } \\
\text { urea }\end{array}$ & $\begin{array}{l}1.5 \% \mathrm{HCHO} \\
\text { treated urea. }\end{array}$ \\
\hline $\begin{array}{l}\text { Dry matter, \% } \\
\% \text { of DM }\end{array}$ & 88.2 & 86.4 & 78.4 & 99.8 & 99.4 \\
\hline \multicolumn{5}{|l|}{$\%$ of DM } & \\
\hline $\begin{array}{l}\text { Ash } \\
\text { Crude protein }{ }^{1} \text { ) }\end{array}$ & $\begin{array}{c}6.6 \\
\left.12.7^{1}\right)\end{array}$ & 9.1 & $\begin{array}{r}11.4 \\
3.8\end{array}$ & $\left.46.4^{2}\right)$ & $\left.46.2^{2}\right)$ \\
\hline Ether extract & 3.3 & 1.6 & 0.8 & - & - \\
\hline Crude fibre & 8.9 & 33.5 & 43.9 & - & - \\
\hline $\mathrm{N}$-free extracts & 68.3 & 48.3 & 40.0 & - & - \\
\hline f.u./kg DM & 1.03 & 0.45 & 0.55 & - & - \\
\hline MJ ME (MAFF)/kg DM & 8.6 & 12.2 & 7.9 & - & - \\
\hline g DCP/f.u. & 91 & 136 & 41 & - & - \\
\hline
\end{tabular}

f.u.(feed unit) $=0.7 \mathrm{~kg}$ starch

1) without urea

$\left.{ }^{2}\right) \mathrm{N} \%$

(1982 d). The dry matter and nitrogen content of the urea were determined by Fischer titration and the Kjeldahl method, respectively. The pre-treatment of the other feed samples was according to SETÄLÄ and SYRJÄLÄ-QVIST(1982 c) and the chemical composition of the feeds was analyzed by the Weende analyses (PALOHEIMO 1969). The digestibility of the straw and hay in vitro were determined by the method of TILLEY and TERRY (1963).

After the test period had lasted for 21 weeks, blood samples were taken from the Vena jugularis before the morning feeding. Plasma proteins, urea, albumin, creatinine, alanine aminotransferase, and aspartate aminotransferase were determined with the analyzer of GILFORD SYSTEM 3500 (Gilford Instrument Laboratories Inc., USA) in the College of Veterinary Medicine.

The rumen contents were sampled immediately after the animals had been slaughtered. The contents were mixed carefully and sampling was performed in different parts of the rumen. The samples were pre-treated as described by SYRJÄLÄ(1972) and the $\mathrm{pH}$ was measured from the rumen fluid. Volatile fatty acids were determined by gas chromatography according to HUIDA (1973). 
Tissue samples were taken from the liver and kidneys at the time of slaughter, and examined for possible changes under the microscope.

\section{Calculations and statistical analyses}

The amino acid requirements suggested by CHALUPA (1975) for growing cattle were used in the calculations. In calculating the intake of amino acids, account was taken of the amino acid composition of the feeds (SETÄLÄ, unpublished) and the composition of the amino acids in the microbial mass (SETÄLÄ and SYRJÄLÄ-QVIST 1982 b). Microbial protein synthesis was calculated using the value of $30 \mathrm{~g} \mathrm{~N} / \mathrm{kg}$ organic matter apparently fermented in the rumen. The amount of organic matter fermented was calculated according to the results of SETÄLÄ and SYRJÄLÄ-QVIST (1982 e), account being taken of the effects of treated and untreated urea (SETÄLÄ 1981).

Urea was calculated as DCP as described by LAMPILA (1968). The differences between the group means were analyzed with the t-test.

\section{Results and discussion}

\section{Feed intake}

The average intakes of total DM in the groups of animals receiving untreated and treated urea were 2.41 and $2.45 \mathrm{~kg} \mathrm{DM} / 100 \mathrm{~kg}$ liveweight respectively, which gives an average value of 91 grams $\mathrm{DM} / \mathrm{kg} \mathrm{W} \mathrm{W}^{0.75}$. The total DM intake did not differ significantly between the groups. PAL and NEGI(1978) also found that formaldehyde-treated urea did not decrease the intake of either $\mathrm{NaOH}$-treated straw or total DM. The palatability of the concentrates (Fig. 1) was equally good in the two groups. The $\mathrm{HCHO}$-urea concentrate was not found to be more palatable, as in the study with lactating cows (SETÄLÄ and SYRJÄLÄ-QVIST $1982 \mathrm{~d}$ ). The use of molassed beet pulp probably increased the palatability of the untreated urea, as suggested by RANDALL et al. (1972).

The animals' intake of urea was about $1.59 \mathrm{grams} / \mathrm{kg} \mathrm{W}^{0.75}$. If this amount is calculated as digestible crude protein (LAMPILA 1968), urea contributed 37.8 and $37.2 \%$ of the DCP requirements in the groups receiving untreated and treated urea, respectively. Without urea, the average crude protein content of the ration DM was $9.6 \pm 1.7 \%$. When urea is taken into account, the corresponding crude protein value was $14.8 \pm 2.1 \%$.

The daily amount of the concentrate per animal was kept constant after the liveweights of the animals in the two groups had passed 198 and $186 \mathrm{~kg}$ (Fig. 1). This was because the animals were fed according to DCP standards suggested by BRÄNNANG and EKMAN-BJÄRESTEN (1965).

During the first 12 weeks of the test period, the proportion of the concentrates in the total DM of the ration was $61-68 \%$. Thereafter the proportion was $47-55 \%$. 


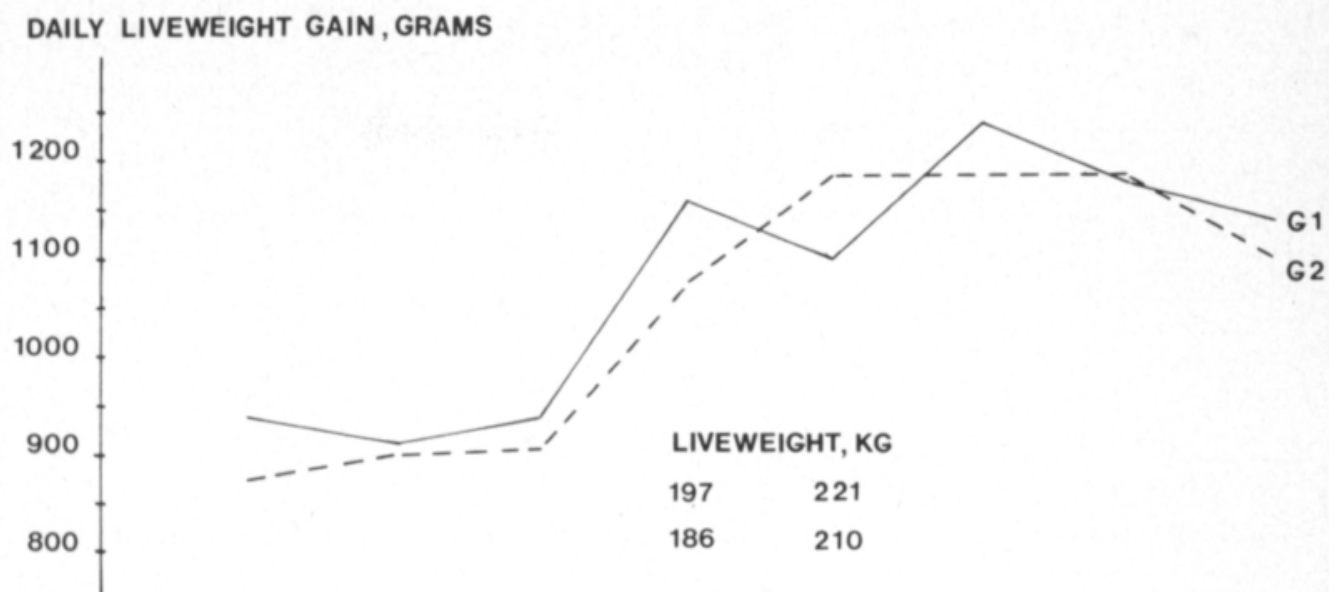

KG DM/ANIMAL/DAY

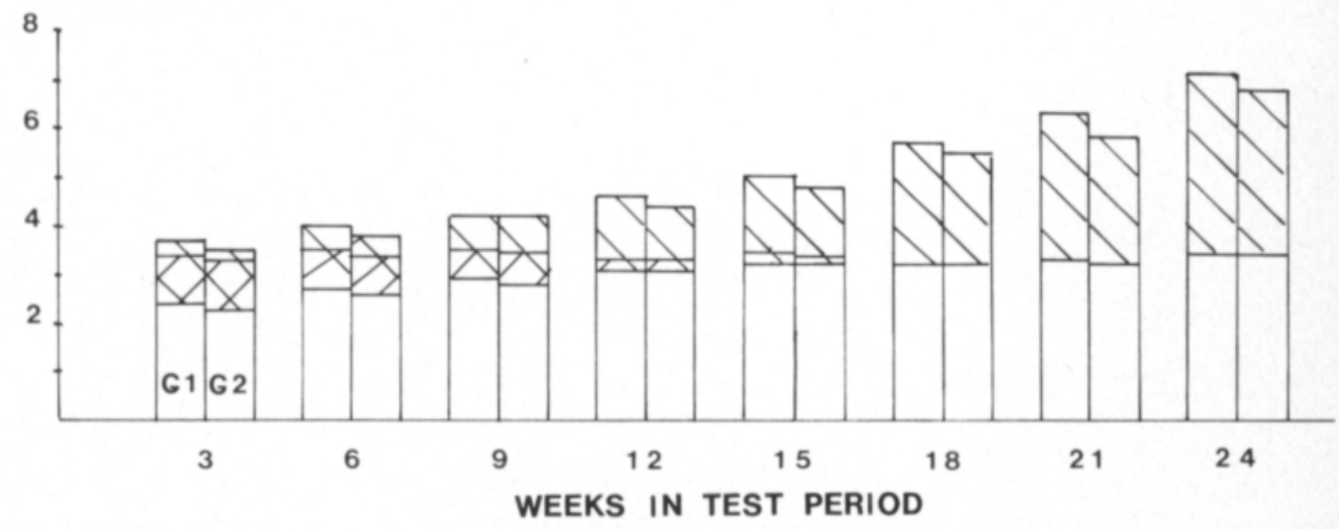

Figure 1. Liveweight gain and feed consumption of the experimental groups. Group $1=\mathrm{G} 1=$ untreated urea, Group $2=\mathrm{G} 2=\mathrm{HCHO}$-treated urea. $\square$ Concentrates, $\square$ hay, $\square \mathrm{NaOH}$-straw.

\section{Rumen fermentation}

There were no significant differences between the animals receiving untreated and treated urea in the concentration of total VFA or in the proportions of different VFA in the rumen (Table 3). The small differences observed were similar to those found by SETÄLÄ and SYRJÄLÄ-QVIST (1982 c) with sheep on a similar diet.

In the microscopic studies the proportion of rumen bacteria tended to be lower in the rumen contents of the animals receiving the $\mathrm{HCHO}$-treated urea. However, no differences were found in the occurence of protozoa.

\section{Growth and feed utilization}

There were no significant differences between the groups in the growth rate, feed utilization or slaughter results of the animals (Fig. 1, Table 4). In earlier papers it has been suggested that the growth rate, and energy and 
Table 3. Parameters for the rumen fermentation in the samples of rumen contents taken after slaughter.

\begin{tabular}{|c|c|c|c|c|}
\hline & \multicolumn{4}{|c|}{ Groups } \\
\hline & \multicolumn{2}{|c|}{ Untreated urea } & \multicolumn{2}{|c|}{$1.5 \% \mathrm{HCHO}$-treated urea } \\
\hline & $\dot{\mathbf{x}}$ & s.d. & $\overline{\mathbf{x}}$ & s.d. \\
\hline $\mathrm{pH}$ & 6.66 & 0.35 & 6.72 & 0.20 \\
\hline VFA, mmoles $/ 100 \mathrm{ml}$ & 13.3 & 3.8 & 14.2 & 2.3 \\
\hline Acetic acid, molar $\%$ & 69.9 & 0.4 & 70.3 & 1.8 \\
\hline Propionic acid, molar $\%$ & 17.9 & 0.6 & 17.6 & 1.2 \\
\hline Iso-, butyric acids, molar \% & 10.9 & 0.5 & 10.9 & 1.4 \\
\hline Iso-, valeric acid, molar \% & 1.2 & 0.3 & 1.2 & 0.2 \\
\hline
\end{tabular}

Table 4. The average age, weight, daily liveweight gain, feed utilization and slaughter results of the groups.

\begin{tabular}{lcc|cc}
\hline & \multicolumn{5}{c}{ Groups } \\
\cline { 2 - 5 } & \multicolumn{3}{c}{ Untreated urea } & \multicolumn{1}{c}{$1.5 \%$ HCHO-treated urea } \\
& \multicolumn{1}{c}{ s.d. } & \multicolumn{1}{c}{ s.d. } \\
\hline Initial age, days ${ }^{1}$ ) & 130 & 10 & 125 & 14 \\
Initial weight, kg ${ }^{1}$ ) & 119.7 & 21 & 114.5 & 16 \\
Final weight, kg & 335.0 & 26 & 319.4 & 13 \\
Daily gain, g/animal & 1081 & 133 & 1050 & 114 \\
f.u./kg gain & 3.8 & 1.0 & 3.9 & 0.7 \\
Slaughter weight, kg & 167 & 15 & 161 & 11 \\
Dressing \% & 49.7 & 0.6 & 50.4 & 1.6 \\
\hline
\end{tabular}

1) at the beginning of the test period.

f.u. (feed unit) $=0.7 \mathrm{~kg}$ starch

nitrogen utilization tend to be improved by increasing frequence in urea feeding (FARRIES and ZGAJNAR 1972) and using slow-release urea in feeding (SZENTMIHALYI 1977, MARGOLIN et al. 1980). According to the results of SETÄLÄ and SYRJÄLÄ-QVIST (1982 a, b, d), this could also have been expected in this experiment, because the crude protein level of the total ration was within the range suggested as optimal for the utilization of treated urea in a diet of this kind. However, it should be noted that the crude protein levels were higher than those suggested for growing cattle by, for instance, ANDERSEN and JUST (1979), GABEL and POPPE (1979), and ROHR (1980). Lower crude protein level in the ration might have revealed differences in nitrogen utilization between the groups, as suggested earlier. This was indicated by the temporary drop in the daily gain of the untreated urea group (Fig. 1), when the crude protein levels were decreased according to standards after the first 12 weeks in the test period. The average daily intakes of net energy at that time were 4.19 and $4.06 \mathrm{f}$.u./animal in the untreated and treated urea groups, respectively.

When the essential amino acids becoming available to the animal from the feeds and microbial protein synthesis were considered in relation to the amino acid requirements (CHALUPA 1975) at a liveweight of about $200 \mathrm{~kg}$, it was found that the limiting amino acid for growth was probably methionine (Fig. 2). According to SETÄLÄ and SYRJÄLÄ-QVIST (1982 b), the proportion of methionine in the bacterial mass was significantly $(\mathrm{P}<0.01)$ higher when 

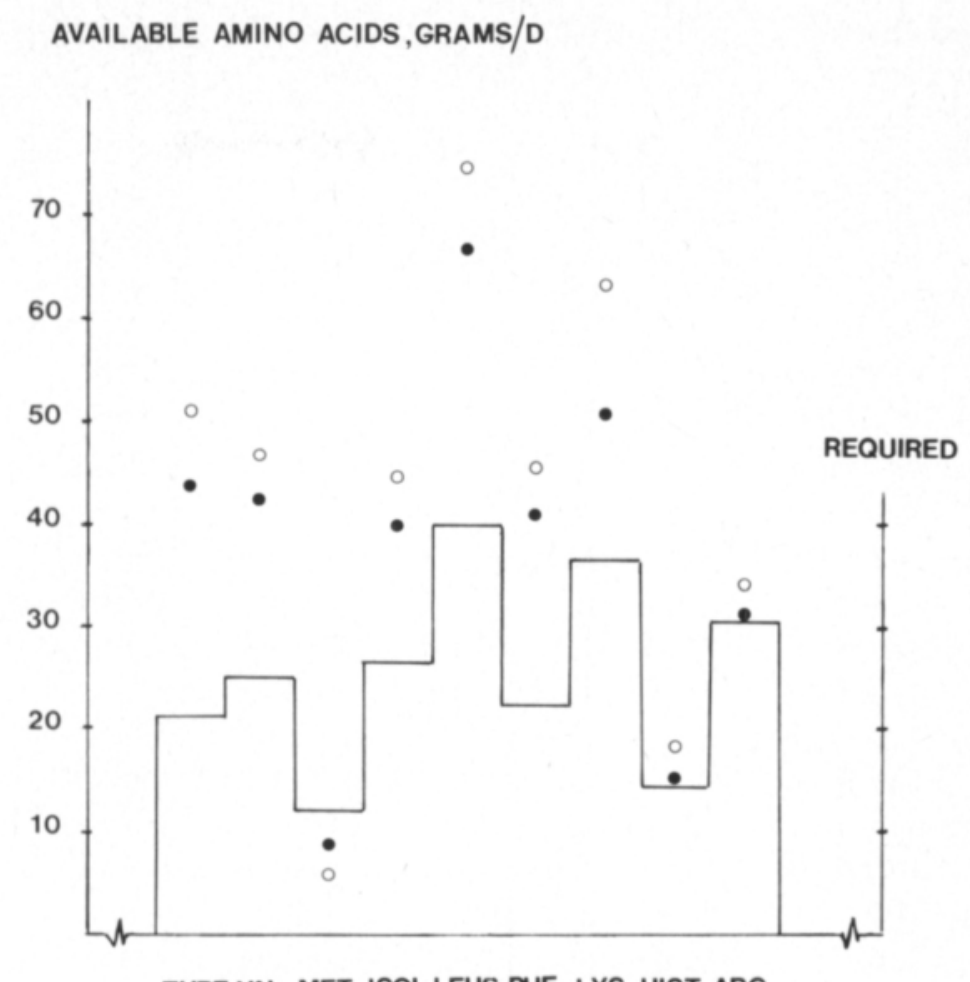

THRE VAL MET ISOL LEUS PHE LYS HIST ARG

\section{AMINO ACIDS}

Figure 2. Supply and requirement of available amino acids as grams d. $\odot$ untreated urea-group, $\bullet$ $\mathrm{HCHO}$-treated urea-group, $\circ$ or $\bullet$ means supply of available amino acids.

$\mathrm{HCHO}$ treated urea was studied and compared with untreated urea in vitro. This may partly explain why the growth rate dropped in the group receiving untreated urea, although this group had a higher feed DM intake and it received more amino acids totally than the group given treated urea.

It has been suggested that urea could replace $33-50 \%$ of the nitrogen in the diet of ruminant calves aged 1-4 months (STEGER et al. 1967, LESKOVA and ZUCKER 1975 and BEDÖ 1980). In our experiment the daily gain clearly improved after the animals had reached a weight of $186-197 \mathrm{~kg}$. Theoretically, urea could in many cases meet the nitrogen requirements almost completely in growing animals that has attained a liveweight of about $300 \mathrm{~kg}$ (ROY 1980). On the other hand, it is possible that at the beginning of the test period the crude protein content of the concentrates was too low and the daily amount of urea fed to the animals too high (c.f. STEGER et. al. 1967 and MATSUOKA et al. 1975).

\section{Composition of blood}

No significant differences were found in the composition of the blood of the animals in the two groups (Table 5). Plasma urea was lower when the 
Table 5. Parameters of blood samples taken 21 weeks after the beginning of the test period.

\begin{tabular}{lcc|cc}
\hline & \multicolumn{4}{c}{ Groups } \\
\cline { 2 - 5 } & \multicolumn{2}{c}{ Untreated urea } & \multicolumn{1}{c}{$1.5 \%$ HCHO-treated urea } \\
& & $\overline{\mathrm{x}}$ & s.d. & \multicolumn{1}{c}{ s.d. } \\
\hline Plasma proteins, g/l & 62.0 & 8.7 & 59.6 & 3.8 \\
Albumin, $\mathrm{g} / 1$ & 32.0 & 3.3 & 32.0 & 1.0 \\
Plasma urea, mmol/1 & 2.1 & 0.85 & 1.7 & 0.78 \\
Aspartate aminotransferase, IU/1 & 75 & 16 & 78 & 12 \\
Alanine aminotransferase, IU/1 & 23 & 2.7 & 21 & 6.3 \\
Creatinine, $\mu$ mol/1 & 101 & 8 & 100 & 10 \\
\hline
\end{tabular}

treated urea was used, which indicates lower and less rapid degradation of urea nitrogen in the digestive tract. This was also noted with sheep fed on the same type of ration (SETÄLÄ and SYRJÄLÄ-QVIST $1982 \mathrm{c}$ ), and receiving urea treated with at least $3 \%$ formaldehyde. However, it is possible that the plasma urea was not entirelly dependent on the degradation of the urea nitrogen in the total ration. According to Figure 2, the essential amino acids other than methionine and histidine, were available to the animal in greater quantity than required and this may have increased the level of urea in the blood (PRESTON et al. 1965, BRODERICK et al. 1974).

WERNER et al. (1975) suggested that formaldehyde is metabolized to formic acid in connection with absorption from the digestive tract. One pathway for eliminating the formic acid absorbed from the digestive tract is an intermediary metabolism in which the kidneys are involved (KAEMMERER and KERBER 1977). In this case changes in activity of the kidneys have been found (MATSCHULLAT 1969, WERNER et al. 1975). In our experiment the plasma concentrations of liver-specific enzymes and creatinine showed no differences (Table 5), thus providing no evidence of changes in the activity of the liver or kidneys (ANON. 1972). The concentrations are within the range recorded for Ayrshire bulls at the age of 9-11 months on a diet of hay and barley (HAAPA 1981).

The health of the animals.

There was one case of slight acidosis in the group receiving treated urea after the period when concentrates contributed more than $60 \%$ of the DM in the ration. Microscopic studies did not show any changes in the tissues of the livers and kidneys of the animals in the different groups.

Acknowledgements. The authors wish to express their gratitude to Kemira Ltd and the College of Veterinary Medicine for co-operation during the experiment. They are also indebted to Prof. Eero Tanhuanpää, Department of Veterinary Medicine, University of Helsinki, for the preparations of the tissue samples from the livers and kidneys. 


\section{References}

ANDERSEN, PREBEN, E. \& JUST, ARNOLD. 1979. Tabeller over fodermidlers sammansaetning m.m. Det kgl. Landhusholdningsselskab, Landhusholdningsselskabets Forlag. København. 56 p.

ANON. 1972. Kliiniset laboratoriotutkimukset. WSOY, Porvoo 581 p.

BEDÖ, S. 1980. Harnstoffverwendung in der Kälberfütterung. Arch. Tierern. 30: 235-238.

BRODERICK, G. A., SATTER, L. D. \& HARPER, A. E. 1974. Use of plasma amino acid concentration to identify limited amino acids for milk production. J. Dairy Sci. 57: 1015-1023.

RÄNNANG, E. \& EKMAN- BJÄRESTEN, I. 1965. Kalv- och ungnötsuppfödning. Ts förlag, Falköping. 228.p.

CHALUPA, W. 1975. Amino-acid nutrition of growing cattle. Tracer studies on non-protein nitrogen for ruminants II. p. 175-194. IAEA, Vienna.

FARRIES, F. E. \& ZGAJNAR, J. 1972. Rohnährstoffverdaulichkeit und Stickstoffverwertung nach Verabreichung hoher Harnstoffmengen. Z. Tierphys. Tierernähr. u. Futtermittelk. 30: 20-32.

GABEL, M. \& POPPE, S. 1979. Betrachtungen zur effektiven Proteinversorgung bei Mastrindern. Arch. Tierern. 29: 504-505.

HAAPA, M. 1981. Personal communication.

HUGHES, J., EDWARDS, I. E. \& TOPPS, J. H. 1980. Response of rapidly growing bulls intensively fed on barley to rumen degradable and undegradable protein supplementation. Anim. Prod. 30:456.

HUIDA, L. 1973. Quantitative determination of volatile fatty acids from rumen sample and silage by gasliquid chromatography. J. Scient. Agric. Soc. Finl. 45: 483-488.

KAEMMERER, K. \& KERBER, H-J. 1977. Formaldehydegeschütztes Sojaprotein im Verträglichkeitsversuch bei Ratten. DLG-Forschungsber. über Tierern. 538004: 2-44.

LAMPILA, M. 1968. Urea supplements in the rations of dairy cows. Ann. Agric. Fenn. 7: 46-58.

LESKOVA, R. \& ZUCKER, H. 1975. Verwertung und Toleranz von Harnstoff beim frühertwöhnten Kalb. Wien. Tierärtzl. Monatschrift 62: 240-245.

MARGOLIN, S. Ya., SYARDZYUK, L. V. \& SUBACH, F. 1980. Effect of different protein sources on meat production of young cattle. Abstract. Vestsi Akademii, Navuk BSSR, Sel'skagaspadarchykti Navuk 2: 82-85.

MASTSCHULLAT, G. 1969. Formalinvergiftung bei Schafen. Tierärztliche Umschau 24: 81-85.

MATSUOKA, S., KUMASE, N., KANZANI, M. \& HASHIZUME, T. 1975. Urea utilization by calves during their growth up to six months of age. Japanese J. of Zootech. Sci. 46: 538-544.

PAL, R. N. \& NEGI, S. S. 1978. Effect of supplementing urea/urea derivates on the utilization of nutrients by bullocks fed untreated, alkali-sprayed wheat straw. Ind. J. Anim. Sci. 48: 656-661.

PALOHEIMO, L. 1969. Weender Analyse. Handbuch der Tierernährung I: 164-171. Hamburg.

PRESTON, R. L., SCHWAKENBURGH, D. D. \& PFANDER, W. H. 1965. Protein utilization in ruminants I. Blood urea nitrogen as affected by protein intake. J. Nutr. 86: 281-287.

RANDALL, R. P., WALLENIUS, R. W., DYER, I. A. \& HILLERS, J. K. 1972. Use of molasses dried beet pulp-urea as a NPN source for young ruminants. J. Anim. Sci. 35: 1083-1086.

ROHR, K. 1980. Meeting the protein and energy requirements for fattening bulls. Proceedings from Paris Beef Pro, European Congress for improved beef productivity. Reprint. 8 p.

ROY, J. H. B. 1980. Utilization of feed protein. Internordic licentiat/doctorand course at Helsinki, 1980. $15 \mathrm{p}$.

SETÄLÄ, J. 1981. Formaldehydi-urean hyväksikäyttö märehtijällä. Lic. thesis, University of Helsinki. 95 p.

— \& SYRJÄLÄ-QVIST, L. 1982 a. The degradation and utilization of formaldehyde-treated urea by rumen microbes in vitro. J. Scient. Agric. Soc. Finl. 54: 15-24

— \& SYRJÄLÄ-QVIST, L. 1982 b. Effect of the crude protein level on the utilization of untreated and formaldehyde-treated urea in vitro. J. Scient. Agric. Soc. Finl. 54: 25-31.

— \& SYRJÄLÄ-QVIST, L. 1982 c. Effect of formaldehyde treated urea on rumen fermentation, ration digestibility and nitrogen utilization. J. Scient. Agric. Soc. Finl. 54: 33-42

— \& SYRJÄLÄ-QVIST, L. 1982 d. Untreated and formaldehyde-treated urea as nitrogen sources for lactating dairy cows. J. Scient. Agric. Soc. Finl. 54:43-52

— \& SYRJÄLÄ-QVIST, L. 1982 e. The ruminal degradation of protein in feeds generally used in Finland. To be published.

STEGER, H., PIATKOWSKI, P. \& VOIGT, J. 1967. Ernährungstudien von Kälbern. 6. Mitt. Der 
Einfluss von Harnstoff in pelletierter Form auf Pansensaft und Blutzusammensetzung bei frühabgesetzten Kälbern. Arch. Tierern. 17: 409-419.

SYRJÄLÄ, L. 1972. Effect of different sucrose, starch and cellulose supplements on the utilization of grass silages by ruminants. Ann. Agric. Fenn. 11: 199-276.

SZENTMIHALYI, S. 1977. Economic and other considerations governing decisions on the advisability of incorporating additional and new sources of protein and non-protein into the diet of beef cattle. Protein and non-protein nitrogen for ruminants. p. 121-128. Pergamon Press.

TILLEY, J. M. A. \& TERRY, R. A. 1963. A two-stage technique for in vitro digestion of forage crops. J. Br. Grassl. Soc. 18: 104-111.

WERNER, E., KRÜGER, S., DUDZUS, M., BEUTLING, D. \& BERGMANN, V. 1975. Formaldehyd als Vergiftungsursache bei Rindern. Monatsch. für Veterinärmed. 30: 244-246.

Ms received April 13, 1982

\title{
Käsittelemätön ja formaldehydillä käsitelty urea nuorten kasvavien liha- nautojen typenlähteenä
}

\author{
Jouko Setälä, Liisa Syrjälä-Qvist ja Pentti Aspila \\ Helsingin yliopisto, kotieläintieteen laitos, 00710 Helsinki 71
}

Tutkimuksessa verrattiin käsittelemätöntä ja 1.5 prosentilla formaldehydiä käsiteltyä ureaa kasvavien lihanautojen typenlähteenä. Koe-eläiminä käytettiin kahdeksaa friisiläisrotuista ja neljää ayrshire-rotuista sonnia, jotka tulivat kokeeseen kahdessa blokissa keskimäärin 3.5 kuukauden iässä. Kokeessa oli aluksi kahden viikon vakiointijakso, jonka kasvutulosten ja rehunhyväksikäytön sekä eläinten painon ja iän perusteella eläimet jaettiin kauden jälkeen kahteen tasavertaiseen ryhmään. Vertailukauden (24 viikkoa) ja vakiointikauden välillä oli siirtokausi (1 viikko), jona aikana eläimet siirrettiin vertailuruokinnoille. Kokeessa eläimet saivat perusrehuina $\mathrm{NaOH}$-käsiteltyä ohran olkea sekä ohra-kaura-melassileike -seosta siten, että kasvutavoitteena oli $1000 \mathrm{grammaa} / \mathrm{eläin/d}$. Vakiointijaksolla eläimet saivat väkirehussaan 2.9 prosenttia käsittelemätöntä ureaa, ja lisäksi valkuaisruokinta toteutettiin soijarouheella normeja vastaavaksi. Vertailujaksolla sai toinen ryhmä käsittelemätöntä ja toinen formaldehydi-käsiteltyä ureaa väkirehuseoksessa siten, että urea muodosti noin 35-40 prosenttia eläinten sulavan raakavalkuaisen tarpeesta. Kahdella ensimmäisellä jaksolla sekä vertailujakson alussa käytettiin myös kuivaa heinää eläinten karkearehuna. Eläimet olivat kokeessa yksilöruokinnalla.

Eri ryhmien välillä ei ollut merkitseviä eroja kasvunopeudessa, rehun hyväksikäytössä ja teurastuloksissa. Myöskään pötsikäymisessä ja veren urea-, albumiini- ja kokonaisproteiiniarvoissa sekä maksan ja munuaisten toimintaa kuvaavien parametrien konsentraatioissa veressä ei ollut merkitseviä eroja ryhmien välillä. 